\title{
Disability in Makindu: A brief by the Kenya Umbrella for Children with Disabilities (KUCD)
}

\section{Alexander Meti}

\section{(2) OpenEdition}

12 Journals

\section{Electronic version}

URL: https://journals.openedition.org/eastafrica/443

DOI: 10.4000 /eastafrica.443

ISSN: 2790-1076

\section{Publisher}

IFRA - Institut Français de Recherche en Afrique

\section{Printed version}

Date of publication: 1 October 2012

Number of pages: 61-63

ISSN: 2071-7245

\section{Electronic reference}

Alexander Meti, "Disability in Makindu: A brief by the Kenya Umbrella for Children with Disabilities (KUCD)", Les Cahiers d'Afrique de l'Est / The East African Review [Online], 46-1 | 2012, Online since 07 May 2019, connection on 10 December 2021. URL: http://journals.openedition.org/eastafrica/443 ; DOl: https://doi.org/10.4000/eastafrica.443

This text was automatically generated on 10 December 2021.

Les Cahiers d'Afrique de l'Est / The East African Review 


\section{Disability in Makindu: A brief by the Kenya Umbrella for Children with Disabilities (KUCD)}

\section{Alexander Meti}

\section{Definition of Disability}

1 KUCD was mandated with establishing the number of disabled people in Makindu. Among the Kamba it was established that disability comprises those who are lame, blind, deaf, dumb, mentally retarded. The following statistics represents cases of disability in the region. It was also noted that some cases such as intellectual and missing some parts of the body were not considered disabilities, yet such conditions many a times leave people vulnerable to mistreatment due to their inability to work or participate in a number of activities.

\section{No.of disabled children in Makindu district}

\begin{tabular}{|c|l|l|}
\hline a. & Visual & 650 \\
\hline b. & Physically & 2,800 \\
\hline c. & Mentally & 610 \\
\hline d. & Deaf & 300 \\
\hline e. & Dumb & 330 \\
\hline f. & Cerebral & 600 \\
\hline g. & Autism & 200 \\
\hline h. & Intellectual & Not determined \\
\hline i. & Missing hand & Not determined \\
\hline
\end{tabular}


\begin{tabular}{|l|l|l|}
\hline j. & Missing foot & Not determined \\
\hline
\end{tabular}

2 From the figures above it is evident that the number of physically disabled people is high yet they receive little attention from the government. It was also noted that many of the disabled people rarely get out of their houses because parents or caretakers feel embarrassed or are too busy to take care of the children.

\section{Causes and prevalence}

3 It was noted that most disabilities in Makindu are caused by diseases such as meningitis, Polioor TB. Other cases of disabilities are the result of birth defects. When a child is hit by mutulo-a Kamba word for sudden serious sickness-a person looses consciousness and sweats profusely and if he/she is not taken to the hospital for treatment in time he may become deaf, dumb or in some instances may get a condition of autism that is difficult to heal. Polio on its part leaves the child paralyzed and the child becomes physically disabled.

\section{Dealing with disability in Makindu}

4 KUCD has come up with the following suggestions to deal with the increasing cases of disability in Makindu:

- Have a centre for disabled children where the disabled children will be taught formal education and various vocational training to empower them with knowledge to better their livelihood.

- There is need for projects to generate money, to be used to empower the disabled children sponsoring them for education, food; good health and housing in an effort to relieve parents of disabled children off the burden child keep up.

- Start mobile health clinics to reach scattered disabled children in the entire Makindu district and its environs.

- Establish a resource centre for professionals for staff capacity building in order to ensure the rehabilitation and management of disabled children.

- Start an appliances workshop to train and also be a source of employment for the trainees after school.

- Periodic local, regional and national children disability prevalence surveys every 1-2 years: this should be done by academic and research institutions and associates the aim is to determine the accuracy of certain categories of disability in particular areas. It would also helping in determining the causes and design actions/precautions measures to be taken at selected areas/regions.

\section{Government/NGO participation}

- There are 14 disability government registered groups in Makindu.

- The government has also adopted strategies to deal with the disabled through the National Council for Persons with Disability (NCPWD), through the Ministry of Gender and Youth Services. It has however been observed that in such government-run institutions service provision is slow and rarely reaches the disabled persons. The process of identification and 
assistance of disabled persons is also discriminative due to the lack of representatives. In the provision of wheelchairs, for example, misunderstandings are always reported.

- NGOs are very reluctant in partnering with local organizations that have the data on the children with disability. interventions in the course of our work.

dedicate our time to the children with disability regardless of sex. such schools to assist in the education of the disabled.

- There is also no trained staff to deal with the children. looked down upon by normal ones due to their slow progression in learning.

\section{KUCD values} all our stakeholders in order to effectively and efficiently work towards the welfare of disabled children.

- There are no special needs schools in Makindu. This has been a big challenge in teaching disabled children both formal and vocational training. Makindu needs urgent efforts to build

- Public primary schools often accommodate some cases of disabilities, but children are

Integrity: We uphold professionalism, honesty, accountability and evidence based

\author{
disabled children.
}

\title{
INDEX
}

\section{Geographical index: Kenya}

\section{AUTHOR}

\section{ALEXANDER METI}

Alexander Meti is the director of Kenya Umbrella of Children with Disability (KUCD), a community-based organization situated in Makindu. 